\title{
Joint Commission of the Empress Shôken Fund No. 77
}

Geneva, July 1986

\section{SIXTY-FIFTH DISTRIBUTION OF INCOME}

The Joint Commission entrusted with the distribution of the income of the Empress Shôken Fund met in Geneva on 10 and 27 March 1986. The Japanese Red Cross Society was represented by His Excellency Ambassador Kazuo Chiba.

The Commission noted the statement of accounts and the situation of the Fund as at 31 December 1985 and confirmed that the balance available amounted to 256,531.36 Swiss francs.

In examining the applications, the Joint Commission reviewed the experiences of the past few years. The Commission noted that the following criteria which it had established were still valid:

a. to restrict the number of allocations, thereby increasing the allocations so as to permit the beneficiary National Societies to implement the plans envisaged;

b. to uphold only those from developing National Societies unable to have their projects financed otherwise and, among such Societies, whenever feasible those which have hitherto benefited least from assistance from the Empress Shôken Fund;

c. to refrain from considering the requests from those National Societies which have not conformed to the requirements under Article 5ter of the Regulations according to which the beneficiary National Societies are expected to report on the use of the allocations received. 
The Joint Commission decided that:

i. allocations be transferred to the beneficiaries only upon presentation of either invoices or proof of purchase;

ii. allocations remaining unclaimed or unused after twelve months are to be withdrawn and added to the amount available for the next distribution.

Twenty-three National Societies submitted requests for allocations from the 65th distribution of income and the Joint Commission decided to make the following grants based on the above-mentioned criteria :

Chilean Red Cross: Sw. fr. 35,000

for the purchase of a 7-tonne truck

Indian Red Cross Society: Sw. fr. 25,000

for the purchase of a vehicle

for training purposes

Indonesian Red Cross: Sw. fr. 30,000

for the purchase of 2 ambulances

Fiji Red Cross Society: Sw. fr. 4,000

for the purchase of 8 wheelchairs

Liberian Red Cross Society: Sw. fr. 50,000

for the purchase of equipment for

blood transfusion

Peruvian Red Cross: Sw. fr. 30,000

for the purchase of equipment

for blood transfusion

Tunisian Red Crescent Society: Sw. fr. 20,000

for the purchase of equipment

for blood transfusion

Uganda Red Cross Society: Sw. fr. 25,000

for the purchase of a vehicle

(5 seater)

Yemen Red Crescent Society (Arab Rep.): Sw. fr. 35,000 for the purchase of equipment for relief supplies 
The Joint Commission also decided that the unused balance of 2,531.36 Swiss francs will be added to the income available for the 66th Distribution.

In accordance with Article 5ter of the Regulations, the beneficiary National Societies are required to report in due course to the Secretariat of the Joint Commission on the use which has been made of the allocations received. The Joint Commission would like this report, accompanied by photographs if possible, to reach it at the latest by the end of the year during which the allocation is used. It furthermore reminds beneficiaries of Article 5bis of the Regulations which prohibits them assigning the grant for purposes other than those specified without the previous consent of the Joint Commission.

In accordance with the Regulations, the 1986 income will be distributed in 1987. To facilitate applications in conformity with the Regulations, the Joint Commission will send in the near future model application forms to all National Societies. Requests for allocation must be submitted to the Secretariat of the Joint Commission before 31 December 1986.

For the Joint Commission

League of Red Cross and Red Crescent Societies

Mr. H. Hoegh

Mr. B. Bergman

Mr. K. Seevaratnam
International Committee of the Red Cross

Mr. M. Aubert (Chairman)

Mr. M. Martin

Mr. S. Nessi 


\section{Empress Shôken Fund}

\section{BALANCE SHEET AS AT 31 DECEMBER 1985}

(Swiss francs)

\begin{abstract}
ISSETS
ecurities in Portfolio:

Bonds in Swiss Francs

(Market Value:

2,696,000.-)

Bonds in Foreign

Currency (Market Value :

$1,563,000 .-1 \ldots .$.
\end{abstract}

$2,671,127.15$

iixed Deposits:

Banque Romande,

Geneva .........

(\$153,913) . . . . . .

locounts receivable:

Recoverable withholding tax ............

Cash at Bank:

MM. Hentsch \& Cie,

Geneva

$59,443.87$

Crédit Suisse, Geneva . .

OTAL

$250,455.08$

$316,036.09$

$17,105.07$

$7,343.15$

$66,787.02$

\section{LIABILITIES AND OWN FUNDS}

Capital at 1.1.1985

$3,328,777.18$

Contribution from the Government of Japan .....

203,658.-

Contribution from the Japanese Red Cross . . . . . 164,401.58

$1,499,900.30$

Contributions from Japanese visitors .........

$1,127.20$

$3,697,963.96$

$256,531.36$

Funds available at 31.12 .85

$566,491.17$

Reserve Against Fluctuations ..........

$598,335.90$

Reserve for Administrative Expenses:

Balance brought forward from previous year ....

$22,213.42$

Transfer from the income statement as per Regulations

$7,466.43$

$29,679.85$

Less:

Administrative expenses for the year $1985 \ldots \ldots$.

$8,397.25 \quad 21,282.60$

Accounts payable

League of Red Cross \& Red Crescent Societies (Current Account) . . . . . . . . .

Allocations to be withdrawn $123,689.71$

TOTAL $\ldots \ldots \ldots$ 


\section{SECURITIES}

Summary Analysis as at 31.12.1985

Evaluation at Market Value

(Swiss francs)

a) Investment by currency

Swiss Francs $\ldots \ldots \ldots \ldots \ldots \ldots$

\begin{tabular}{rr}
$2,696,825$ & $63.30 \%$ \\
624,648 & $14.67 \%$ \\
496,140 & $11.64 \%$ \\
442,512 & $10.39 \%$ \\
\hline $4,260,125$ & $100 \%$ \\
\hline
\end{tabular}

b) Investment by country

Japan

$2,437,844$

$57.23 \%$

Netherlands

496,140

442,512

$11.64 \%$

Germany (Fed. Rep.)

360,600

$10.39 \%$

International (World Bank)

188,500

$8.46 \%$

Switzerland

148,379

$4.43 \%$

New Zealand

133,900

$3.48 \%$

France ... .

52,250

$3.14 \%$

Great Britain

$\begin{array}{r}52,250 \\ \quad 4,260,125 \\ \hline\end{array}$
$1.23 \%$ $100 \%$ 


\section{INCOME}

Interest income from securities $207,510.25$

Interest on bank deposits $41,371.48$ $248,881.73$

\section{EXPENSES}

$3.0 \%$ of total income above transferred to the provision for administrative expenses (Article 7 of the statutes of the Fund)

\section{RESULTS}

Excess of income over expenditure for 1985

$241,415.30$

\section{STATEMENT OF APPROPRIATION}

Balance carried forward from previous year $\ldots \ldots \ldots \ldots$

Less:

Sixty-fourth distribution of income for the year 1984 to 10 National Societies and the Henry Dunant Institute

Excess of income over expenditure for the year 1985

The accounts of the Empress Shôken Fund have been audited by $l a$ Société Fiduciaire OFOR $S A$. The financial report is obtainable from the League of Red Cross and Red Crescent Societies.*

\footnotetext{
* Original in French.
} 